\title{
Clinical importance of myeloid antigen expression in Moroccan patients with adult B-lineage acute lymphoblastic leukemia.
}

\author{
A. LAHJOUJI ${ }^{1, \star}$, F. BACHIR ${ }^{1}$, S. BENNANI ${ }^{1}$, S. BENCHEKROUN ${ }^{2}$, S. AMZAZI ${ }^{3}$, R. E. AOUAD ${ }^{1}$
}

${ }^{1}$ Laboratoire de cytometrie en flux, Institut National d'Hygiène, Rabat, Maroc; ${ }^{2}$ Service d'Hématologie et d'Oncologie pédiatrique, Hôpital 20 Août, Casablanca, Maroc; ${ }^{3}$ Université Mohamed V-Agdal, Faculté des Sciences, UFR Biochimie Immunologie, Rabat, Maroc

*Correspondence: lahjouji_ali@yahoo.fr

Received November 23, 2012/ Accepted February 4, 2013

\begin{abstract}
The prognostic significance of myeloid antigen (MyAg) expression in acute lymphoblastic leukemias (ALL), especially in adult patients, is still controversial. In the present report, frequency and clinical significance of MyAg (CD13 and/or CD33) in blast cells were assessed in 80 consecutive adult ( $\geq 18$ years) patients with B-lineage acute lymphoblastic leukemia (B-ALL), representing $66.7 \%$ of 120 patients diagnosed as having ALL during the study period. Immunophenotyping was used to classify leukemic cells as B or T lymphoblasts and to identify the aberrant expression of myeloid-associated antigens. MyAg expression was documented in 52.5\% of the 80 B-ALL cases analyzed. CD13 was the most commonly antigen expressed (36.3\%) followed by CD33 (28.8\%). No significant associations were found between the expression of MyAg and the presence of known adverse prognostic features (eg: age $>30$ years, male gender, high WBC count and Philadelphia positivity). Also, we failed to observe any statistically significant difference between MyAg-positive and MyAg-negative patients in terms of achievement of complete remission and overall survival at 3 years. This study demonstrates that the presence of MyAg on lymphoblastic cells lacks prognostic value In Moroccan patients with adult B-ALL.
\end{abstract}

Key words: adult B acute lymphoblastic leukemia, myeloid antigen, immunophenotyping, prognosis.

Acute lymphoblastic leukemia (ALL) is biologically and clinically a heterogeneous group of diseases characterized by an uncontrolled proliferation of precursor lymphoid cells with maturation stopped at various stages. As a consequence, those cells accumulate in the bone marrow, normal hematopoiesis is stopped and replaced by leukemic cells which finally appear in the blood and may infiltrate different organs. Leukemic blasts in ALL express normal lymphoid differentiation antigens [1]. In addition, these often display aberrant or uncommon phenotypes comprising the presence of crosslineage antigens, i.e. myeloid antigens ( $\mathrm{MyAg}$ ) in lymphoid cells, or abnormal patterns of expression of normal antigens, which probably reflect underlying molecular abnormalities $[2,3]$. The clinical significance of MyAg expression in ALL remains controversial. Although the few early adult ALL studies had shown an inferior outcome for MyAg+ ALL patients, the other published series have found similar induction and treatment outcomes for patients with MyAg negative and MyAg positive ALL $[4,5]$. The aim of this study is to evalu- ate the frequency of aberrant myeloid antigens expression in Moroccan B lineage ALL (B-ALL) and to correlate them with known prognostic factors such as gender, age, WBC count and with treatment outcome.

\section{Patients and methods}

This retrospective study was conducted on 80 consecutive adult ( $\geq 18$ years) patients with B-ALL, identified by immunophenotyping, among 120 patients newly diagnosed with ALL (other than L3 subtypes) between January 2006 to December 2009, at the Hematology and Oncology Hopital Casablanca, Morocco.

The diagnosis was made by standard morphologic examination and cytochemical analysis of bone marrow smears according to the criteria established by the FrenchAmerican- British (FAB) [5] Cooperative Study Group and by immunophenotyping with a panel of mAbs against myeloid-and lymphoid-associated antigens as suggested by the 
Table 1. MARALL HR 2006 protocol detail

\begin{tabular}{|c|c|}
\hline Phase & Treatment regimen \\
\hline PREPHASE & Prednisone: $60 \mathrm{mg} / \mathrm{m}^{2}$ for 2 doses (per os or IV), on $\mathrm{d} 1-7$ \\
\hline \multicolumn{2}{|l|}{ INDUCTION } \\
\hline Prednisone & $60 \mathrm{mg} / \mathrm{m}^{2} / \mathrm{d}$ (for 3 doses, per os or IV) on $\mathrm{d} 8-21$ \\
\hline Vincristine & $1,5 \mathrm{mg} / \mathrm{m}^{2} /$ injection (DIV $1 \mathrm{mn}$ ) d8, d15, d22, d29 \\
\hline L-Asparaginase & $6.000 \mathrm{UI} / \mathrm{m}^{2}$ (IM): 9 injections between $\mathrm{d} 22$ and $\mathrm{d} 38$ (every two days) \\
\hline Daunorubicin & $40 \mathrm{mg} / \mathrm{m}^{2} /$ injection (SIV 60mn): d8, d15, d22, d29 \\
\hline TIT therapy & $\mathrm{d} 8, \mathrm{~d} 15$ and $\mathrm{d} 22$ if $\mathrm{SNC}+$ at diagnosis \\
\hline \multicolumn{2}{|l|}{ CONSOLIDATION } \\
\hline Mercaptopurine & $50 \mathrm{mg} / \mathrm{m}^{2} / \mathrm{d}$ (per os): $\mathrm{d} 1$ to $\mathrm{d} 21$ and $\mathrm{d} 29$ to $\mathrm{d} 49$ \\
\hline Cyclophosphamide & $750 \mathrm{mg} / \mathrm{m}^{2} / \mathrm{d}(\mathrm{SIV} 30 \mathrm{mn}): \mathrm{d} 1$ and $\mathrm{d} 15$ \\
\hline Cytarabine & $30 \mathrm{mg} / \mathrm{m}^{2} /$ injection $: \mathrm{x} 2 / \mathrm{d}(\mathrm{SC}): \mathrm{d} 1-\mathrm{d} 2, \mathrm{~d} 8-\mathrm{d} 9, \mathrm{~d} 15-\mathrm{d} 16$ \\
\hline Vincristine & $1,5 \mathrm{mg} / \mathrm{m} 2 /$ injection (SIV $1 \mathrm{mn}$ ): $\mathrm{d} 29$ and $\mathrm{d} 43$ \\
\hline Prednisone & $40 \mathrm{mg} / \mathrm{m}^{2} / \mathrm{d}(3$ doses per os or IV): $\mathrm{d} 29$ to $\mathrm{d} 35$ \\
\hline Méthotrexate & $25 \mathrm{mg} / \mathrm{m}^{2} /$ dose (per os): $\mathrm{d} 36$ and $5.000 \mathrm{mg} / \mathrm{m}^{2} / \mathrm{d}$ (Perfusion in $3 \mathrm{H}$ ): $\mathrm{d} 29$ and $\mathrm{d} 43$ \\
\hline ITT & $\mathrm{d} 1, \mathrm{~d} 29$ and $\mathrm{d} 43$ \\
\hline \multicolumn{2}{|c|}{ INTENSIFICATION $\mathrm{N}^{\circ} 1$} \\
\hline Dexamethasone & $10 \mathrm{mg} / \mathrm{m}^{2} / \mathrm{d}(3$ doses per os or IV): $\mathrm{d} 1$ to $\mathrm{d} 15$ \\
\hline Vincristine & $3 \mathrm{mg} / \mathrm{m}^{2} /$ injection (DIV $1 \mathrm{mn}$ ): $\mathrm{d} 1, \mathrm{~d} 8, \mathrm{~d} 15$ \\
\hline L-Asparaginase & $6.000 \mathrm{UI} / \mathrm{m}^{2} /$ injection $(\mathrm{IM}): \mathrm{d} 3, \mathrm{~d} 5, \mathrm{~d} 7 \mathrm{~d} 9, \mathrm{~d} 11, \mathrm{~d} 13$ \\
\hline Doxorubicin & $25 \mathrm{mg} / \mathrm{m}^{2} /$ injection (SIV in $60 \mathrm{mn}$ ): d1, d8, d15 \\
\hline Mercaptopurine & $50 \mathrm{mg} / \mathrm{m}^{2} / \mathrm{d}$ (per os): $\mathrm{d} 29$ to $\mathrm{d} 49$ \\
\hline Cyclophosphamide & $750 \mathrm{mg} / \mathrm{m}^{2} / \mathrm{d}(\mathrm{SIV}$ in $60 \mathrm{mn}): \mathrm{d} 29$ and $\mathrm{d} 43$ \\
\hline Cytarabine & $30 \mathrm{mg} / \mathrm{m}^{2} /$ injection: $\mathrm{x} 2 / \mathrm{d}(\mathrm{SC}): \mathrm{d} 29-\mathrm{d} 30, \mathrm{~d} 36-\mathrm{d} 37, \mathrm{~d} 43-\mathrm{d} 44$ \\
\hline ITT & $\mathrm{d} 1, \mathrm{~d} 15, \mathrm{~d} 29$ and $\mathrm{d} 43$ if SNC+ \\
\hline \multicolumn{2}{|l|}{ INTERPHASE } \\
\hline Vincristine & $1,5 \mathrm{mg} / \mathrm{m}^{2} /$ injection (DIV $1 \mathrm{mn}$ ): d1, d15, d29, d43 \\
\hline Prednisone & $40 \mathrm{mg} / \mathrm{m}^{2} / \mathrm{d}$ ( 3 doses per os): $\mathrm{d} 1$ to $\mathrm{d} 7 / \mathrm{d} 29$ to $\mathrm{d} 36$ \\
\hline Mercaptopurine & $50 \mathrm{mg} / \mathrm{m}^{2} / \mathrm{d}($ per os) $: \mathrm{d} 1$ to $\mathrm{d} 49$ \\
\hline Méthotrexate & $25 \mathrm{mg} / \mathrm{m}^{2} / \mathrm{dose}$ (per os) : d8,d15,d22,d36, and $5.000 \mathrm{mg} / \mathrm{m}^{2} / \mathrm{d}$ (SIV $\left.3 \mathrm{~h}\right): \mathrm{d} 1, \mathrm{~d} 29, \mathrm{~d} 43$ \\
\hline ITT & $\mathrm{d} 1, \mathrm{~d} 15, \mathrm{~d} 29$ and $\mathrm{J} 43$ if no irradiated \\
\hline \multicolumn{2}{|c|}{ INTENSIFICATION No2 } \\
\hline Prednisone & $40 \mathrm{mg} / \mathrm{m}^{2} / \mathrm{d}$ (3 doses per os): $\mathrm{d} 1$ to $\mathrm{d} 15$ \\
\hline Vincristine & $1,5 \mathrm{mg} / \mathrm{m}^{2} /$ injection (DIV $1 \mathrm{mn}$ ): $\mathrm{d} 1, \mathrm{~d} 8, \mathrm{~d} 15$ \\
\hline L-Asparaginase & $6.000 \mathrm{UI} / \mathrm{m}^{2} /$ injection (IM): $\mathrm{d} 3, \mathrm{~d} 5, \mathrm{~d} 7, \mathrm{~d} 9, \mathrm{~d} 11, \mathrm{~d} 13$ \\
\hline Daunorubicin & $30 \mathrm{mg} / \mathrm{m}^{2} /$ injection (SIV $60 \mathrm{mn}$ ): d1, d8, d15 \\
\hline Mercaptopurine & $50 \mathrm{mg} / \mathrm{m}^{2} / \mathrm{d}$ (per os): $\mathrm{d} 29$ to $\mathrm{d} 49$ \\
\hline Cyclophosphamide & $1000 \mathrm{mg} / \mathrm{m}^{2} /$ injection (SIV $30 \mathrm{mn}$ ): $\mathrm{d} 29$ \\
\hline Cytarabine & $30 \mathrm{mg} / \mathrm{m} 2 /$ injection $\times 2 / \mathrm{d}(\mathrm{SC}): \mathrm{d} 29-\mathrm{d} 30, \mathrm{~d} 36-\mathrm{d} 37, \mathrm{~d} 43-\mathrm{d} 44$ \\
\hline ITT & D1 if no irradiated \\
\hline \multicolumn{2}{|c|}{ MAINTENANCE TRAITEMENT } \\
\hline Mercaptopurine & $75 \mathrm{mg} / \mathrm{m} 2 / \mathrm{d}$ \\
\hline Méthotrexate & $25 \mathrm{mg} / \mathrm{m}^{2} /$ week/for 24 months \\
\hline Vincristine & $1,5 \mathrm{mg} / \mathrm{m}^{2}$ by injection in $\mathrm{d} 1$ \\
\hline Dexaméthasone & $6 \mathrm{mg} / \mathrm{m}^{2} / \mathrm{j}$ in 3 doses per os $\mathrm{d} 1$ to $\mathrm{d} 5$ during the first 24 month \\
\hline ITT & At reinductions 3,6 and 9 \\
\hline
\end{tabular}

European Group for the Immunological Characterization of Leukemias (EGIL) group [6]. Bone marrow (BM) or peripheral blood (PB) samples were collected, prior to treatment, on ethylenediaminetetraacetic acid tubes. All patients were consented to the routine laboratory and hospital procedures including blood and bone marrow studies.

Immunophenotyping analysis. Immunophenotyping analyses were performed at the Cytometery Laboratory of 

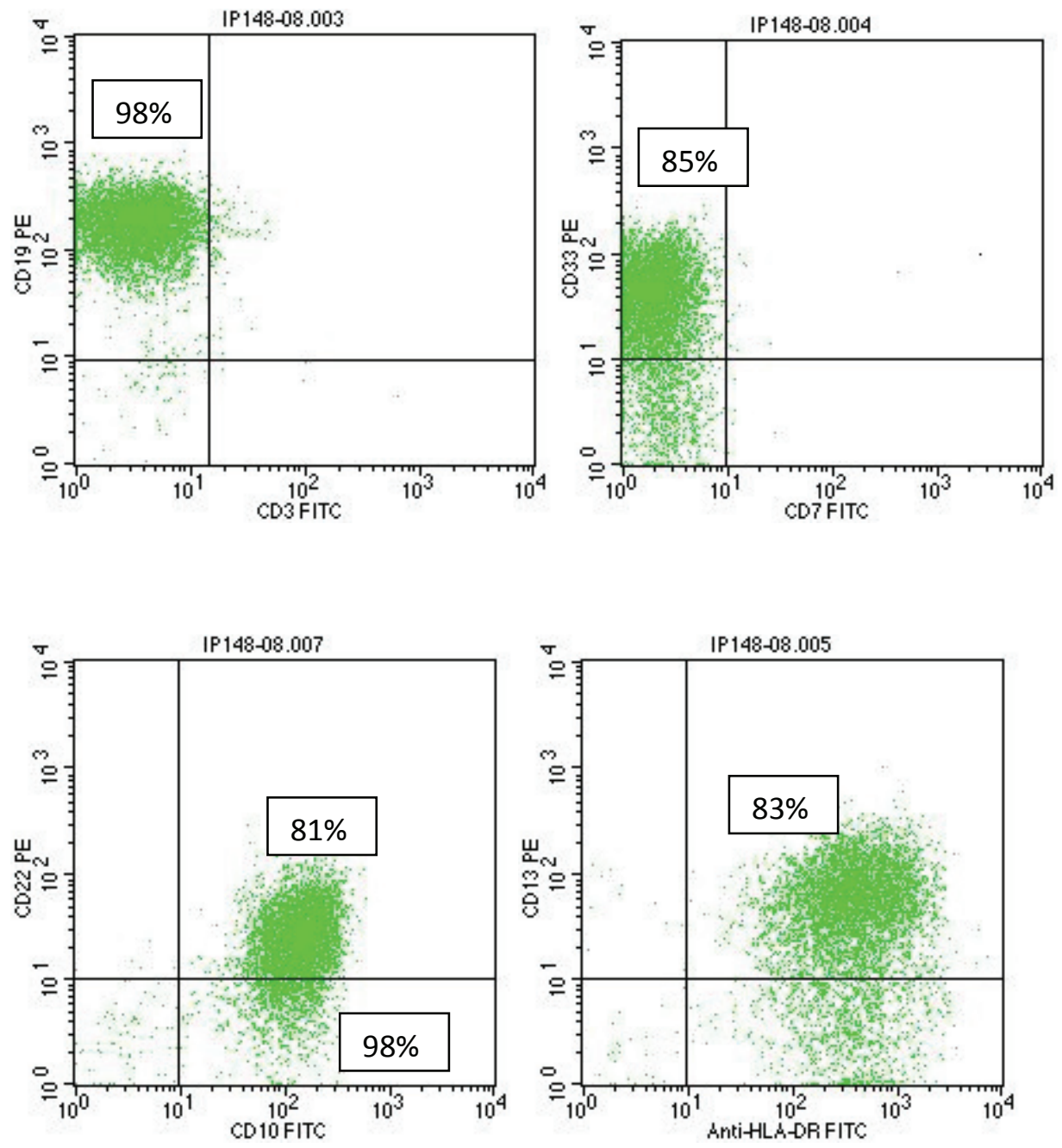

Figure 1. A typical case of B-ALL showing aberrant expression of myeloid markers: CD13 (83\%) and CD33 (85\%). Almost all of the gated blasts was positive for B-cell specific marker: CD 19 (98\%), CD22 (81\%) and CD10 (98\%).

the National Hygiene Institute of Morocco using an acute leukemia panel of monoclonal antibodies consisting of CD1a, CD3, CD4, CD5, CD7, CD8 (T-cell lineage), CD10 (CALLA), CD19, CD22, CD79a (B-cell lineage), CD13, CD14, CD15, CD33, CD36, CD41a, CD61 (myeloid markers), CD34, CD117(c-kit) and TdT. Abnormal populations were recognized by CD45/SSC gating, which was the base of calculating the positive rate of leukaemia-related antigens expressed on the abnormal cells. We regarded $>20 \%$ of cell expression in a tube as positive expression.

Cytogenetic analysis. In cytogenetic analysis standard G-banding techniques were used to stain metaphases from unstimulated cultures in bone marrow cells.

Chemotherapy. Patients were treated using the National protocol MARALL HR 2006 that consists of induction, consolidation, intensification and maintenance phases, as detailed in table1.
Response criteria and statistical analysis. Complete remission response (CR) required normal marrow cellularity with less than $5 \%$ of blast cells. Overall survival (OS) was defined as time from the date of diagnosis to the date of death or last follow-up. Patient characteristics and CR rates were compared using the exact $\chi 2$ test. Survival curves were calculated according to the methods of Kaplan and Meier [7] and compared between groups with the log-rank test [8]. SPSS 17.0 version software was used for the analysis.

\section{Results}

Analysis of MyAg expression in B ALL Patients. B-ALL patients were classified as MyAg+ if $>20 \%$ of blasts were positive for $\mathrm{CD} 13$ or $\mathrm{CD} 33$, or both. An example of a typical $\mathrm{B}$-ALL expressing the CD13 and the CD33 is shown in Figure 1. Overall, MyAg (CD13 and/or CD33) expression was 


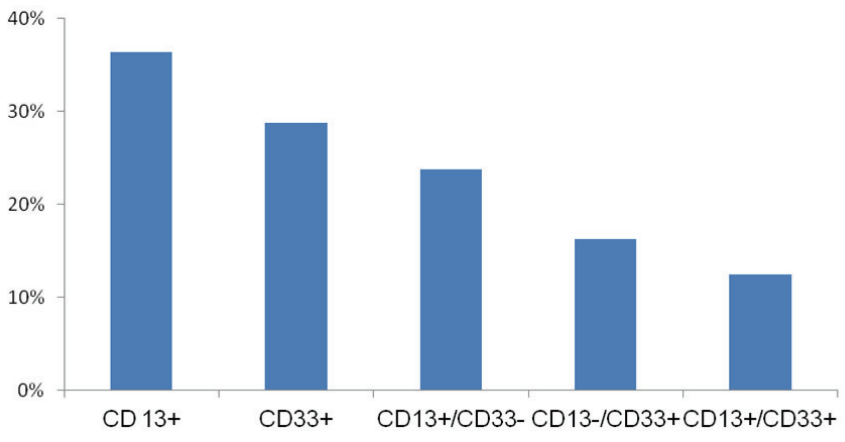

Figure 2. Reactivity to Myeloid-Associated Antibodies Cases with B-ALL.

documented in $52.5 \%$ B-ALL cases analyzed, more frequently CD13 (36.3\%; with a proportion of positive cells ranging from 21 to $95 \%)$ than CD33 (28.8\%; with a proportion of positive cells ranging from 26 to 97\%). Both CD13 and CD33 antigens were expressed in 10 cases (12.5\%) (Figure 2). Table 2 shows the immunophenotype of Moroccan adult B- ALL patients with $(\mathrm{n}=42)$ and without $(\mathrm{n}=38)$ MyAg expression. All tested cases (both MyAg+ and MyAg- patients) were positive for CD19, CD22 and CD79a but were negative for CD3 and MPO. The expression frequency of CD34 was significantly higher in MyAg+ group than in MyAg- group $(p<0.001)$. In contrast, expression frequency of CD10, CD45 and TdT was similar for both groups $(p=0.547, p=0.859$ and $p=0.111$ respectively).

Patient characteristics. The Clinical and biological characteristics at diagnosis of the $80 \mathrm{~B}$-ALL patients are shown in Table 3. There were 37 females and 43 males, with a median age of 34 years and a median white blood cell count of $21300 / \mu \mathrm{l}$. Anemia (hemoglobin $<10.0 \mathrm{~g} / \mathrm{dL}$ ) was present in $89.6 \%$ of patients and thrombocytopenia (platelet count $<100000 / \mu \mathrm{l}$ ) in $85.5 \%$. Physical examination revealed hepatomegaly $(>2 \mathrm{~cm})$ in $23.3 \%$, splenomegaly $(>2 \mathrm{~cm}$ ) in $40.3 \%$ and lymphadenopathy in $57.7 \%$ of patients. Among the patients classified in FAB, 10\% showed L1 and 78.7\% L2 morphology. Cytogenetic data were available for 62 cases. 44 patients $(71.0 \%)$ had an abnormal karyotype including 17 cases (27.4\%) with Ph chro-

Table 2. Incidence of antigen markers in relation to MyAg expression, $n(\%)$.

\begin{tabular}{cccc}
\hline CD & MyAg+ $(\mathbf{n}=\mathbf{4 2})$ & MyAg- $(\mathbf{n}=\mathbf{3 8})$ & P value \\
\hline CD3 and cCD3 & $0(0)$ & $0(0)$ & - \\
CD10 & $26(62)$ & $21(55)$ & 0.547 \\
CD19 & $42(100)$ & $38(100)$ & - \\
CD22 & $42(100)$ & $38(100)$ & - \\
CD34 & $39(93)$ & $22(58)$ & $<0.001$ \\
CD45 & $37(90)$ & $32(91)$ & 0.859 \\
CD79a & $42(100)$ & $38(100)$ & - \\
TdT & $39(91)$ & $28(78)$ & 0.111 \\
MPO & $0(0)$ & $0(0)$ & - \\
\hline
\end{tabular}

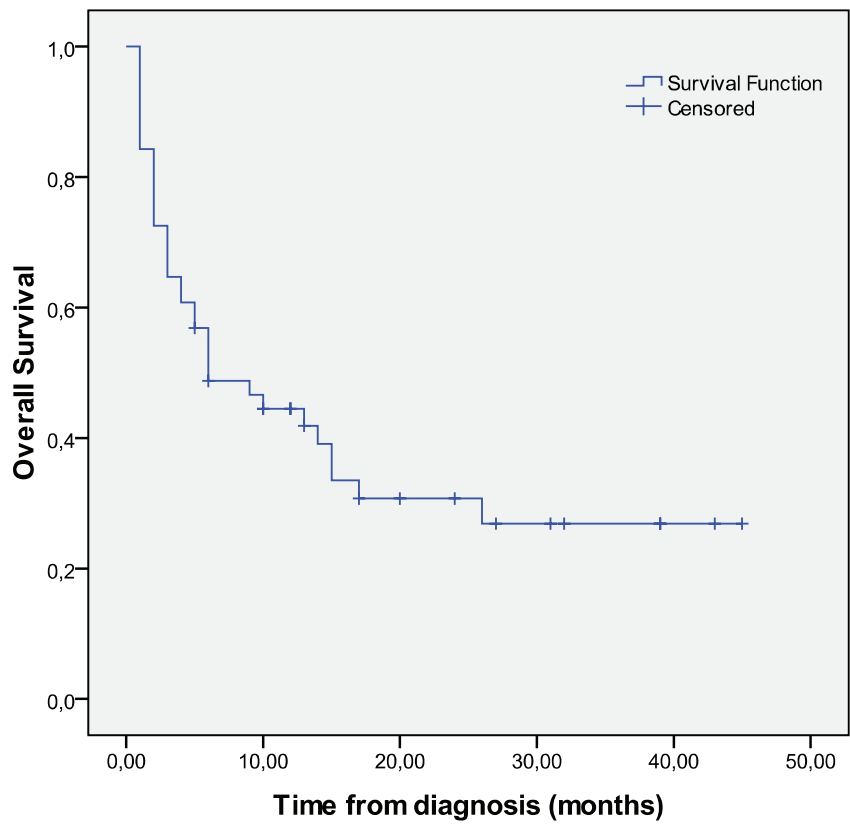

Figure 3. Kaplan-Meier estimates of overall survival rates among all patients analyzed in this study.

mosome positivity. On the basis of the positivity for at least 1 myeloid marker, we stratified the patients into 2 groups: MyAg+ and MyAg- groups table 3. The median ages were 34.5 years (18-66) and 30 years (18-60) for MyAg (+) and MyAg (-) patients, respectively. No significant differences were observed in MyAg+ versus MyAg- patients in relation to adverse clinical presenting features including male gender $(P=0.849)$, age $>30$ years $(P=0.382)$, high WBC $(P=0.587)$, hepatomegaly $(P=0.495)$, splenomegaly $(P=0.611)$, degree of anemia $(P=0.633)$ or presence of Philadelphy chromosome $(P=0.174)$.

Treatment outcome. Data on survival from diagnosis were available in 52 patients, which included 27 patients with MyAg+ B-ALL and 25 patients with MyAg- B-ALL. All this patients has received treatment according to the National MARALL 2006 protocol. The overall complete remission (CR) rate post-induction therapy was $48 \%$ and the estimated 3 -year OS rates were $27 \% \pm 7 \%$ (Figure 3 ). The prognostic relevance of MyAg expression and other presenting features are analyzed and summarized in table 4 . Older age was associated with inferior OS using a cut-off age of $>30$ (Figure $4 ; p=0.038$ ). High WBC $(>50000 / \mu \mathrm{l})$ was associated with a lower CR rate $(p=0.026)$ but did not affect significantly OS rate (figure 5; $p=0.192$ ). Considering the MyAg expression, there were no significant difference in CR rate or in OS between patients with ALL expressing B antigens only and those expressing $\mathrm{B}$ plus myeloid antigens (figure $6 ; p=0.983$ ). Comparisons of karyotypes showed that the OS rate was significantly worse for karyotypes exhibiting the $\mathrm{t}(4 ; 11)$ abnormality or the $\mathrm{Ph}$ chromosome (Figure $7 ; p=0.031$ ). 
Table 3. Clinical Features in MyAg+ and MyAg- B-ALL patients

\begin{tabular}{|c|c|c|c|c|}
\hline \multirow[b]{2}{*}{ Characteristics } & \multicolumn{3}{|c|}{$\mathrm{n}(\%)$} & \multirow[b]{2}{*}{$P$ value } \\
\hline & MyAg+ B ALL & MyAg- B ALL & Total & \\
\hline \multicolumn{5}{|l|}{ Sex } \\
\hline Male & $23(54.8)$ & $20(52.6)$ & $43(53.7)$ & 0.849 \\
\hline Female & $19(45.2)$ & $18(47.4 \%)$ & $37(46.3)$ & \\
\hline \multicolumn{5}{|l|}{ Age } \\
\hline Median (range) & $34.5(18-66)$ & $30(18-60)$ & $34(18-66)$ & \\
\hline$<30$ years & $18(42.9)$ & $20(52.6)$ & $38(47.5)$ & 0.382 \\
\hline 30 years or older & $24(57.1 \%)$ & $18(47.7)$ & $42(52.5)$ & \\
\hline \multicolumn{5}{|l|}{$\operatorname{FAB}^{\star}(\%)$} \\
\hline LAL1 & $5(11.9)$ & $3(7.9)$ & $8(10.0)$ & \\
\hline LAL2 & $34(81.0)$ & $29(76.3)$ & $63(78.7)$ & 0.427 \\
\hline NS & $3(7.1)$ & $6(15.8)$ & $9(11.3)$ & \\
\hline \multicolumn{5}{|l|}{ Tumoral syndrome } \\
\hline Lymphadenopathy & $26(61.9)$ & $19(52.8)$ & $45(57.7)$ & 0.416 \\
\hline Splenomegaly, $2 \mathrm{~cm}$ or larger & $18(42.9)$ & $13(37.1)$ & $31(40.3)$ & 0.611 \\
\hline Hepatomegaly, $2 \mathrm{~cm}$ or larger & $11(26.2)$ & $6(19.4)$ & $17(23.3)$ & 0.495 \\
\hline \multicolumn{5}{|l|}{ Laboratory data } \\
\hline \multicolumn{5}{|l|}{ Leukocyte count } \\
\hline Mediane (range) & $21100(510-268000)$ & $22000(800-450000)$ & $21300(510-450000)$ & \\
\hline$<50000 / \mu \mathrm{l}$ & $30(71.4)$ & $25(65.8)$ & $55(68.8)$ & 0.587 \\
\hline$>50000 / \mu \mathrm{l}$ & $12(28.6)$ & $13(34.2)$ & $25(31.2)$ & \\
\hline \multicolumn{5}{|l|}{ Hemoglobin level } \\
\hline Mediane (range) & $6.9(3.2-12.8)$ & $7.1(3.0-11.8)$ & $6.9(3.0-12.8)$ & \\
\hline$<10 \mathrm{~g} / \mathrm{dl}$ & $37(88.1)$ & $32(91.4)$ & $69(89.6)$ & 0.633 \\
\hline$>10 \mathrm{~g} / \mathrm{dl}$ & $5(11.9)$ & $3(8.6)$ & $8(10.4)$ & \\
\hline \multicolumn{5}{|l|}{ Platelet count } \\
\hline Mediane (range) & $34000(2900-570000)$ & 30000 (2000-192000) & $30000(2000-570000)$ & \\
\hline$<100000$ & $34(81.0)$ & $31(91.2)$ & $65(85.5)$ & 0.208 \\
\hline$>100000$ & $8(19.0)$ & $3(8.8)$ & $11(14.5)$ & \\
\hline \multicolumn{5}{|l|}{ Cytogenetics, $N=62$} \\
\hline Normal karyotype & $11(28.2)$ & $7(30.4)$ & $18(29.0)$ & 0.852 \\
\hline Abnormal karyotype & $28(71.8)$ & $16(69.6)$ & $44(71.0)$ & \\
\hline $\mathrm{Ph}$ Chromosome & $13(33.3)$ & $4(17.4)$ & $17(27.4)$ & 0.174 \\
\hline $\mathrm{t}(4 ; 11)$ & $1(2.5)$ & $3(13.0)$ & $4(6.5)$ & 0.140 \\
\hline
\end{tabular}

NS, not specified; FAB, French-American-British classification ( ${ }^{\star}$ L3 subtype excluded); Ph, Philadelphia chromosome.

\section{Discussion}

Flow cytometric immunophenotyping remains an indispensable tool for the diagnosis, classification, staging, and monitoring of hematologic neoplasms. The last 10 years have seen advances in flow cytometry instrumentation and availability of an expanded range of antibodies to myeloid- and lymphoid-associated differentiation antigens has led to the recognition of acute leukaemias with blasts co-expressing antigens associated with different lineages. Investigations of the past decade support the concept of two broad categories of acute leukaemias with aberrant or disparate expression of lineageassociated features [reviewed in Refs. 9,10]. Acute leukaemias in the most common category, also referred to as MyAg+ ALL and LyAg+ AML, have distinct immunophenotypic, genotypic and clinical features characteristic of a strong commitment to a single lineage but with one or several aberrant features of another lineage. The second category of acute leukaemias display a mixture of antigenic and often also genotypic features that make it unclear whether the leukaemic blasts are committed to a single lineage of differentiation, i.e. true Biphenotypic Acute Leukemia (BAL). More recently, strict and well-defined criteria have been proposed that were aimed at distinguishing BAL from those cases with aberrant expression of one or more markers from another lineage (e.g. MyAg+ ALL and LyAg+ AML) $[6-9,11]$. In contrast to BAL, My+ ALL and Ly+ AML occur frequently. In our experience, it occurs in about $52 \%$ of all B ALL cases analyzed. In earlier studies, the incidence of aberrant phenotypes in adult ALL, both overall and with regard to individual antigens, has varied from 10 to $54 \%[12,13]$. This 


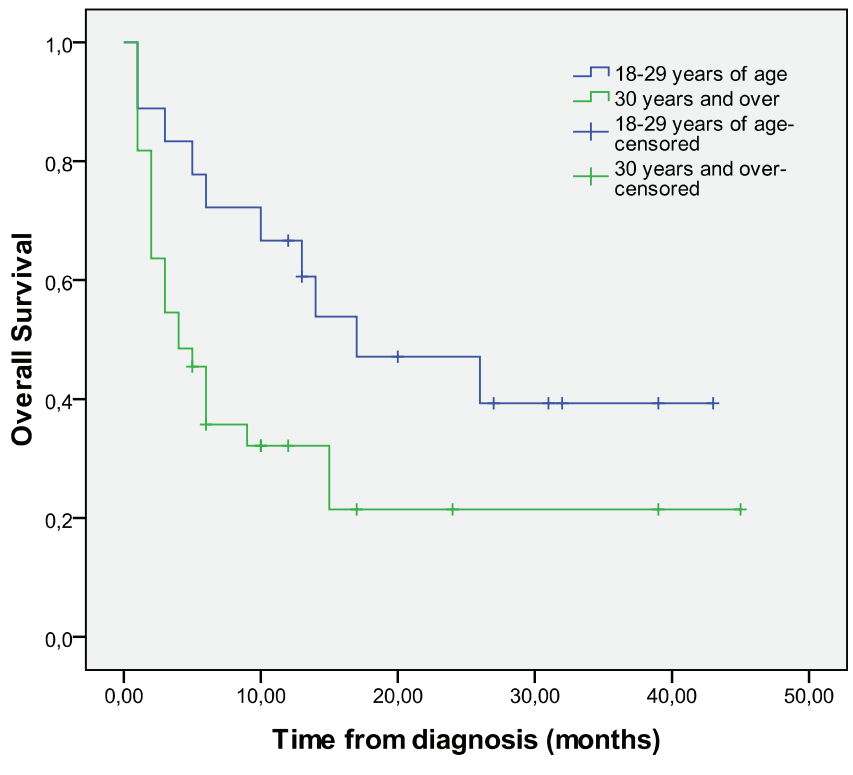

Figure 4. Age differences in Kaplan-Meier estimates of overall survival (OS) rates. Estimated 3-years OS were $39 \% \pm 12.5 \%$ for patients aged 18 trhough 29 years and $21 \% \pm 8 \%$ for patients aged 30 years and over $(\mathrm{P}=0.038)$.

wide variability has been attributed to a number of reasons, including the lack of consistent criteria for the diagnosis of MyAg+ ALL or LyAg+ AML and defining positive results, the utilization of various panels of $\mathrm{mAbs}$, the lack of lineage specificity of most of the mAbs used, and several technical factors $[14-15,16]$. MyAg+ B ALL patients in the current study has frequency of CD34 than MyAg- patients which is consistent with a previous report that, in pediatric and adult patients, CD34 expression was correlated with myeloid antigen expression. CD34 is a $110 \mathrm{kD}$ integral membrane protein thought to

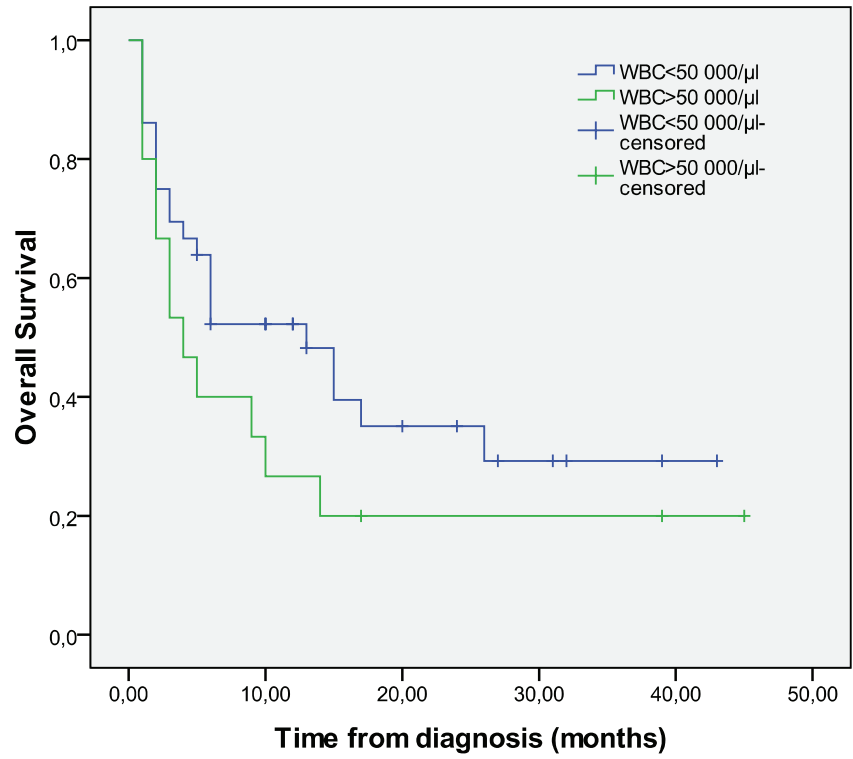

Figure 5. White blood cell count at diagnosis (WBC) differences in Kaplan-Meier estimates of overall survival (OS) rates among B-ALL patients.

be expressed normally by immature hematopoietic progenitor cells. Therefore, expression of the CD34 antigens by MyAg+ ALL cells further supports the hypothesis that MyAg+ ALL arises via transformation of an immature progenitor cell. In view of previous studies pointing to myeloid-antigen expression as a predictor of poor prognosis in both childhood and adult ALL [reviewed in Refs. 17, 18], considerable interest has focused on the cell-biological features and clinical significance of this subgroup of acute leukaemias. Several studies, including more than 4000 paediatric patients with ALL [19-20, 21] and

Table 4. Impact of MyAg expression and others presenting features on RC and OS.

\begin{tabular}{|c|c|c|c|c|}
\hline Variable & $\mathrm{RC}$ & $p$ & 3-years OS & $p^{*}$ \\
\hline \multicolumn{5}{|l|}{ Age } \\
\hline$<30 \mathrm{y}$ & $12(60)$ & & $39 \% \pm 12.5 \%$ & \\
\hline$>30 y$ & $13(42)$ & 0.208 & $21 \% \pm 8.0 \%$ & 0.038 \\
\hline \multicolumn{5}{|l|}{ Sex } \\
\hline Male & $18(58)$ & & $26 \% \pm 10 \%$ & \\
\hline female & $7(33)$ & 0.080 & $31 \% \pm 9.5 \%$ & 0.669 \\
\hline \multicolumn{5}{|l|}{ WBC } \\
\hline$<50000 / \mu \mathrm{l}$ & $20(59)$ & & $29 \pm 9 \%$ & \\
\hline$>50000 / \mu \mathrm{l}$ & $4(25)$ & 0.026 & $20 \pm 10 \%$ & 0.192 \\
\hline \multicolumn{5}{|c|}{ MyAg expression } \\
\hline MyAg+ & $20(52)$ & & $26 \% \pm 9.5 \%$ & \\
\hline MyAg- & $16(44)$ & 0.571 & $31 \% \pm 10 \%$ & 0.929 \\
\hline \multicolumn{5}{|l|}{ Cytogenetics } \\
\hline Normal & $7(58)$ & & $67 \pm 13.5 \%$ & \\
\hline Abnormal & $10(40)$ & 0.295 & $15 \pm 9 \%$ & 0.023 \\
\hline
\end{tabular}

${ }^{*} p$ values were obtained by log rank test. RC: Complete response $n(\%)$; OS: Estimated 3 years overall survival in percentage (\%) \pm SD. 


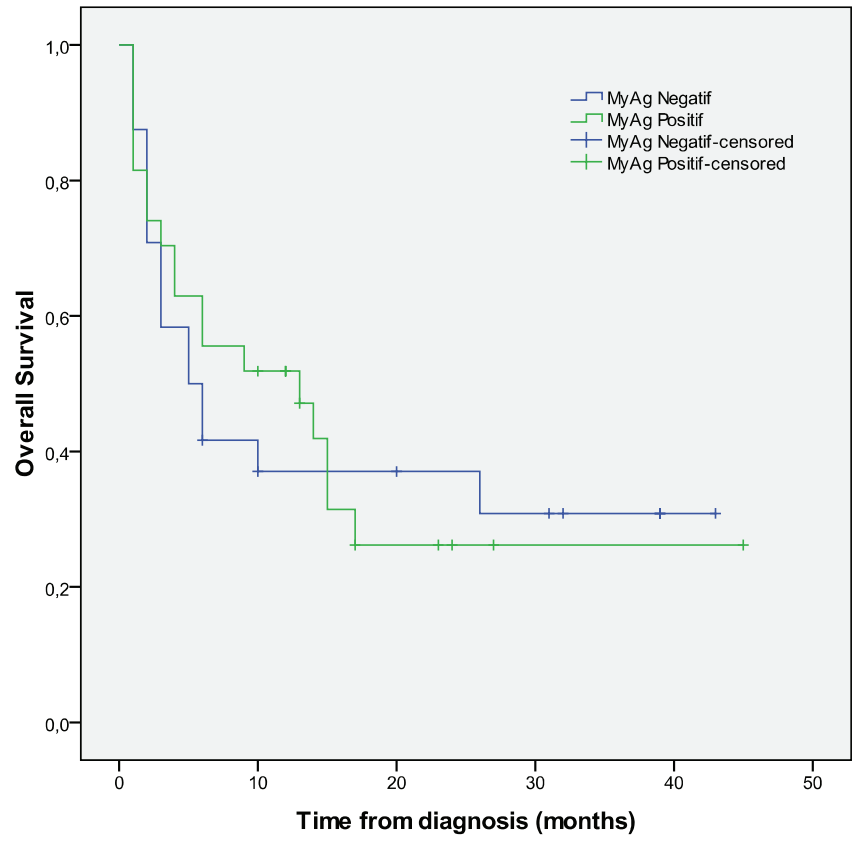

Figure 6. Overall survival (OS) curves of the cases according to myeloid antigen expression. Estimated 3-years OS rate were $26 \% \pm 9.5 \%$ for MyAg+ B-ALL and $31 \% \pm 10 \%$ for MyAg-B-All patients $(\mathrm{P}=0.983)$.

other data in almost 5000 children treated within the ALLBFM 86, 90 and 95 trials [22,23], have failed to demonstrate an association between MyAg+ ALL and poor outcome. In some of these studies, myeloid-associated antigen expression was clearly associated with certain genetic features of leukaemic cells, particularly MLL and ETV6-AML1 rearrangements $[21,23]$. In contrast to childhood MyAg+ ALL, the clinical importance of myeloid-associated antigen expression in adult ALL is still unknown. The presence of myeloid-associated antigens has been associated with a poor outcome in some, but not all studies [reviewed in Ref. 4]. In our analysis of the clinical importance of myeloid antigen expression, we have found no statistically significant difference between patients with and without aberrant phenotypes in relation to well know adverse presenting features although a trend for a higher incidence of $\mathrm{Ph}$ chromosome in the MyAg+ B-ALL group. Importantly, we could not find any significant impact of MyAg expression on clinical outcome with regards to both complete remission rate and overall survival. However, we cannot exclude that the lack of any statistical difference might be due to the relatively small number of patients, especially only few cases with karyotypic findings were available in this study.

\section{Conclusion}

Our data, although limited by relatively small numbers of patients, has resulted in several important observations. These include, first, B-ALL with aberrant MyAg expression is com-

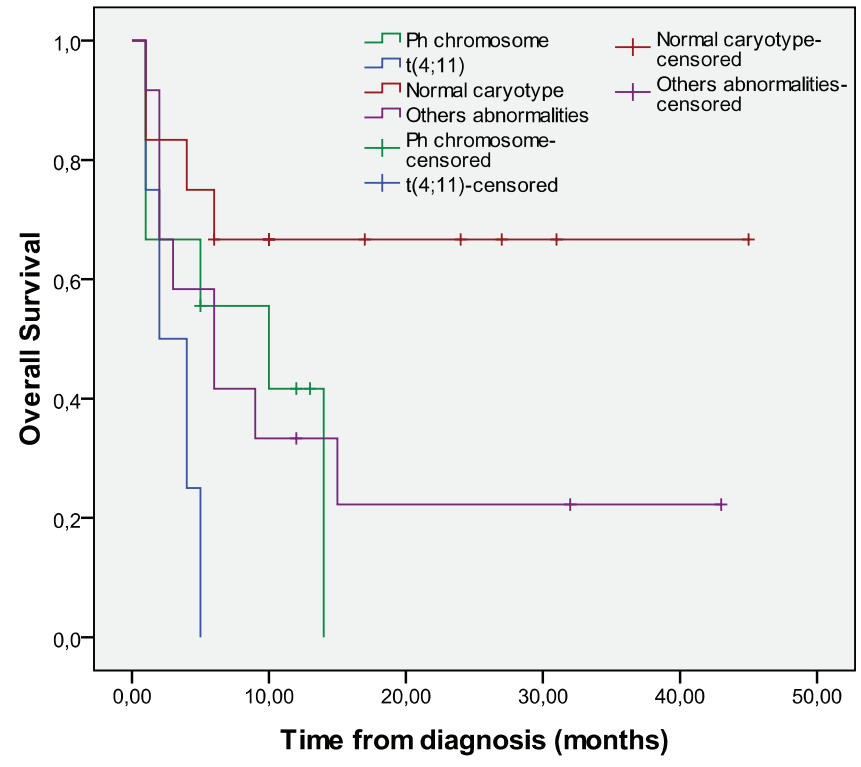

Figure 7. Karyotypic differences in Kaplan-Meier estimates of Overall Survival $(O S)$ rates. Estimated 3-years OS rates were $67 \% \pm 13.5 \%$ for a normal karyotype, $0 \%$ for the $t(4 ; 11)$ abnormality and the $\mathrm{Ph}$ chromosome and $22 \% \pm 13 \%$ for others.

mon in Moroccan adult patients and is to be distinguished from biphenotypic leukemia. Second, flow cytometric analysis of aberrant MyAg expression may be helpful for the detection of minimal residual disease in a large number of adult B-ALL cases, i.e. about $52 \%$ in our study. Lastly, our data, and those obtained by other groups, suggest that the MyAg expression lacks prognostic value in adult B-ALL.

\section{References}

[1] BASSO G, BULDINI B, DE ZL, ORFAO A. New methodologic approaches for immunophenotyping acute leukemias. Haematologica 2001; 86: 675 - 692.

[2] HRUSAK O, PORWIT-MACDONALD A. Antigen expression patterns reflecting genotype of acute leukemias. Leukemia 2002; 16: 1233 - 1258. http://dx.doi.org/10.1038/ sj.leu. 2402504

[3] MACEDO A, ORFAO A, VIDRIALES MB, LOPEZ-BERGES MC, VALVERDE B, et al. Characterization of aberrant phenotypes in acute myeloblastic leukemia. Ann Hematol 1995; 70: 189 - 194. http://dx.doi.org/10.1007/BF01700374

[4] SCHABATH R, RATEI R AND LUDWIG W. The prognostic significance of antigen expression in leukaemia. Best Practice \& Research Clinical Haematology 2003; 16 : 613-628. http:// dx.doi.org/10.1016/S1521-6926(03)00087-2

[5] LUDWIG WD, HAFERLACH T \& SCHOCH C. Classification of acute leukemias: perspective 1. In Pui CH (ed. ) Treatment of Acute Leukemias: New Directions for Clinical Research. Totowa, NJ: Humana Press Inc, 2003, pp 3-41. 
[6] BENNETT JM, CATOVSKY D, DANIEL MT, FLANDRIN G, GALTON DA, et al. Proposals for the classification of the acute leukaemias. French- American-British (FAB) co-operative group. Br J Haematol 1976; 33: 451-8. http://dx.doi. org/10.1111/j.1365-2141.1976.tb03563.x

[7] BENE MC, CASTOLDI G, KNAPP Wet al. Proposals for the immunological classification of acute leukemias. European Group for the Immunological Characterization of Leukemias (EGIL). Leukemia 1995; 9: 1783-1786.

[8] KAPLAN ER, MEIER P Non-parametric estimation from in complete observations. J Am Stat Assoc 1958; 53: 457-481 http://dx.doi.org/10.1080/01621459.1958.10501452

[9] PETO R, PIKE MC: Conservatism of the approximation (O-E)2/E in the log-rank test for survival data or tumour incidence data. Biometrics 1973; 29: 579-584. http://dx.doi. org/10.2307/2529177

[10] BEHM F. Classification of acute leukemias: perspective 2. In Pui CH (ed. ) Treatment of Acute Leukemias: New Directions for Clinical Research. Totowa, NJ: Humana Press Inc, 2003, pp 43-58.

[11] WHO, Pathology and Genetics of Tumours of Haematopoietic and Lymphoid Tissues. Lyon, France: IARC Press, 2001.

[12] BENE' MC, BERNIER M, CASASNOVAS RO et al. The reliability and specificity of c-kit for the diagnosis of acute myeloid leukemias and undifferentiated leukemias. The European Group for the Immunological Classification of Leukemias (EGIL). Blood 1998; 92: 596-599.

[13] LAPORT GF, LARSON RA Treatment of acute lymphoblastic leukemia in adults. Semin Oncol 1997; 24: 70-82.

[14] CZUCZMAN MS, DODGE RK, STEWART CC, et al Value of immunophenotype in intensively treated adult acute lymphoblastic leukemia: Cancer and Leukemia Group B Study 8364. Blood 1999; 93: 3931-3939.

[15] HANSON CA, ABAZA M, SHELDON S et al. Acute biphenotypic leukemia: immunophenotypic and cytogenetic analysis. British Journal of Haematology 1993; 84: 49-60. http://dx.doi. org/10.1111/j.1365-2141.1993.tb03024.x
[16] DREXLER HG \& LUDWIG WD. Incidence and clinical relevance of myeloid antigen-positive acute lymphoblastic leukemia. Recent Results in Cancer Reseach 1993; 131: 53-66. http://dx.doi.org/10.1007/978-3-642-84895-7 6

[17] KHALIDI HS, CHANG KL, MEDEIROS LJ et al. Acute lymphoblastic leukemia. Survey of immunophenotype, French-American-British classification, frequency of myeloid antigen expression, and karyotypic abnormalities in 210 pediatric and adult cases. American Journal of Clinical Pathology 1999; 111: 467-476.

[18] LUDWIG WD, RAGHAVACHAR A \& THIEL E. Immunophenotypic classification of acute lymphoblastic leukemia. Baillie're's Clinical Haematology 1994; 7: 235-262. http:// dx.doi.org/10.1016/S0950-3536(05)80201-X

[19] UCKUN FM, SATHER HN, GAYNON PS et al. Clinical features and treatment outcome of children with myeloid antigen positive acute lymphoblastic leukemia: a report from the Children's Cancer Group. Blood 1997; 90: 28-35.

[20] PUTTI MC, RONDELLI R, COCITO MG et al. Expression of myeloid markers lacks prognostic impact in children treated for acute lymphoblastic leukemia: Italian experience in AIEOP-ALL 88-91 studies. Blood 1998; 92: 795-801.

[21] PUI CH, RUBNITZ R, HANCOCK ML et al. Reappraisal of the clinical and biologic significance of myeloidassociated antigen expression in childhood acute lymphoblastic leukemia. Journal of Clinical Oncology 1998; 16: 3768-3773.

[22] LUDWIG WD, HARBOTT J, BARTRAM CR et al. Incidence and prognostic significance of immunophenotypic subgroups in childhood acute lymphoblastic leukemia: experience of the BFM study 86. Recent Results in Cancer Research 1993; 131: 269-282. http://dx.doi.org/10.1007/978-3-642-84895-7 24

[23] LUDWIG WD, HARBOTT J, RIEDER H, et al. Incidence, biologic features and treatment outcome of myeloidantigenpositive acute lymphoblastic leukemia (My p ALL). In Buchner T, et al. (eds) Acute Leukemias IV. Prognostic Factors. Berlin: Springer, 1994, pp 24. http://dx.doi.org/10.1007/978-3-642$\underline{78350-0 \quad 4}$ 